\title{
ANODIZATION OF Ti-BASED MATERIALS FOR BIOMEDICAL APPLICATIONS: A REVIEW
}

\author{
Dragana R. Barjaktarevici, , Ivana Lj. Cvijović-Alagić2 , Ivana D. Dimićl, \\ Veljko R. Đokićl, Marko P. Rakin ${ }^{1}$ \\ ${ }^{1}$ University of Belgrade, Faculty of Technology and Metallurgy, \\ Karnegijeva 411120 Belgrade, Serbia \\ ${ }^{2}$ University of Belgrade, Institute of Nuclear Sciences "Vinča", \\ P.O. Box 522, 11001 Belgrade, Serbia
}

Received 24.06.2016

Accepted 28.07.2016

\begin{abstract}
Commercially pure titanium (cpTi) and titanium alloys are the most commonly used metallic biomaterials. Biomedical requirements for the successful usage of metallic implant materials include their high mechanical strength, low elastic modulus, excellent biocompatibility and high corrosion resistance. It is evident that the response of a biomaterial implanted into the human body depends entirely on its biocompatibility and surface properties. Therefore, in order to improve the performance of biomaterials in biological systems modification of their surface is necessary. One of most commonly used method of implant materials surface modification is electrochemical anodization and this method is reviewed in the present work. Aim of the presented review article is to explain the electrochemical anodization process and the way in which the nanotubes are formed by anodization on the metallic material surface. Influence of anodizing parameters on the nanotubes characteristics, such as nanotube diameter, length and nanotubular layer thickness, are described, as well as the anodized nanotubes influence on the material surface properties, corrosion resistance and biocompatibility.

Keywords: Titanium-based materials, implant material bioactivation, anodization, anodization conditions, nanotubular layer
\end{abstract}

\section{Introduction}

Titanium (Ti) and titanium alloys are considered to be one of the most significant biomaterials due to their resistance to body fluid effects, great tensile strength,

\footnotetext{
* Corresponding author: Dragana Barjaktarević,draganabarjaktarevic@gmail.com
} 
flexibility, high corrosion resistance and specific combination of strength and biocompatibility [1]. Numerous applications of titanium-based materials can be found in biomedicine, for instance in devices for artificial hearts, structural applications such as screws and dental implant pins, and dental and orthopedic prostheses [2]. Commercially pure titanium (cpTi) is considered to be one of the best biocompatible metallic materials for dental applications, because its surface properties result in the spontaneous formation of a stable passive oxide layer. On the other hand, the Ti-6Al-4V alloy, as $\alpha+\beta$ type titanium alloy, has been used as structural biomaterial for manufacturing orthopedic prostheses and dental implants owing to its excellent specific strength, corrosion resistance, and biocompatible characteristics. However, it has been recently reported that the release of vanadium ions from the alloy during its use might cause health problems due to their toxicity [3]. For this reason, there is growing research activity on developing vanadium-free titanium alloys for biomedical applications with a good combination of biocompatibility, corrosion resistance and mechanical properties similar to those of Ti-6Al-4V.

Recently, $\beta$ type Ti alloys containing $\mathrm{Nb}, \mathrm{Zr}$, Ta, Mo, Sn, etc. have attracted considerable attention especially for orthopedic implants applications [1]. Their unique combination of mechanical properties, low elastic modulus, superior corrosion resistance, no allergic problems, and excellent biocompatibility make them attractive material of modern age. Moreover, it is found that their elastic modulus can be significantly reduced by adjusting the concentration of $\beta$ stabilizing elements influencing in that way stress shielding effect avoidance.

Titanium and its alloys, due to their self-organized oxide layer, which protects the surface from corrosion and prevents ion release, are widely accepted as metallic implant materials [4,5]. Titanium is a reactive material and has a very high affinity for oxygen, which means that if the metal is in the presence of air or oxidizing media, as is the case in a biological system when a bioliquid surrounds the metal, the protective thin oxide film (about 3-8 $\mathrm{nm}$ in thickness) is formed spontaneously and instantly and its disruption or damage is repaired immediately [4,6]. The nature, composition and thickness of the protective oxide layers formed on titanium-based materials depend on the environmental conditions and alloy composition [6], while the stability of this layer depends strongly on its composition, structure and thickness [7]. Usually, the composition of the protective oxide film is based mainly on $\mathrm{TiO}_{2}, \mathrm{Ti}_{2} \mathrm{O}_{3}$ or $\mathrm{TiO}$.

It is important to underline that the behavior of the implant material is not only governed by the bulk material (critical in determining the biological performance), but also by its surface properties (surface chemistry and structure), which are crucial factors in the interactions of the material with the surrounding tissue.

\section{Surface modification of titanium and its alloys}

The surface of an implant often needs some kind of modification to optimize the properties of the implant and to maximize its bioactivity when interfacing with natural tissue. These methods are known as surface treatments or modifications, and can be classified into four categories: mechanical, physical, chemical and biochemical surface modifications. Chemical surface modifications include chemical treatment (with acid, hydrogen peroxide and alkaline solutions), electrochemical processes i.e. anodic oxidation, the sol-gel process and chemical vapor deposition [8]. 
Primarily, surface treatments of implant titanium alloys are needed in order to achieve better and more rapid bonding to bone [9]. The goal is to improve bioactivity, biocompatibility, wear and corrosion resistance of titanium-based materials for their biomedical applications. In most of the cases electrochemical surface modifications are performed by connecting a metallic implant device to the positive pole of the electrical circuit followed by its immersion in an electrolytic solution containing ion substance or oxidants. This methodology can lead to the deposition or installation of some ions on the material surface with the possibility to change the surface properties [10]. Electrochemical surface modification is initially galvanostatic process with a constant current density until the system reaches the desired voltage, after which the process continues at the same voltage during definite time. The electrochemical cell consists of one power supply and two electrodes: platinum or pure graphitic cathode as the control electrode and one titanium sample serving anode as the working electrode. Before the experiment starts titanium samples are polished with SiC paper (from 180 to 2000 grit) and cleaned in distilled water. As a result of the anodic oxidation nanotube oxide layer is obtained. The morphology and structure of obtained nanotubular layer depends on the substrate characteristics, solution composition and parameters of the electrochemical anodizing process.

Portan et al. [11] examined titanium dioxide nanotube layers, which were obtained by the electrochemical anodizing method. The surface modification process lasted $8 \mathrm{~h}$ at $25 \mathrm{~V}$ and in a $1 \mathrm{wt} . \%$ hydrofluoric acid solution. Schematic overview of this anodization process is presented in Figure 1.

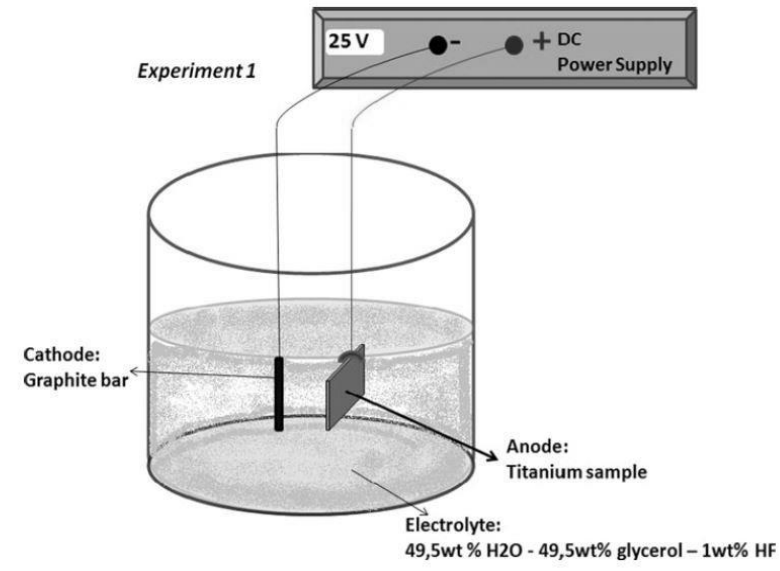

Fig. 1. Schematic overview of the anodizing process [11].

\section{Anodization conditions influence on titanium nanotubes formation}

The most commonly used electrolytes in titanium anodizing are strong acids, e.g. $\mathrm{H}_{2} \mathrm{SO}_{4}, \mathrm{H}_{3} \mathrm{PO}_{4}, \mathrm{HNO}_{3}$, and $\mathrm{HF}$, present in the form of: (i) an aqueous acidic solution containing $\mathrm{F}^{-}$ions; (ii) an aqueous buffered solution; or (iii) a non aqueous electrolyte containing $\mathrm{F}^{-}$ions with or without a trace amount of $\mathrm{H}_{2} \mathrm{O}$ [8]. The type of electrolyte used and electric conditions applied during anodization process can affect the surface morphology, chemical composition, and crystalline structure of the oxide films formed 
by anodic oxidation [12]. When strong acids are used as electrolytic solutions, the oxide layer will be dissolved. The dissolution of the oxide layer creates micro or nano pores on titanium surface. In order to form self-ordering nanotubular oxide layers, presence of the fluoride $\left(\mathrm{F}^{-}\right)$ions in the electrolyte is desired [13]. A key feature of the $\mathrm{F}^{-}$ions is their ability to form soluble metal-fluoride complexes. The metal-fluoride complex helps the prevention of metallic oxides (MOx) layers formation at the tubular bottom, but it also leads to mild but steady chemical dissolution of the MOx. Another important factor is that $\mathrm{F}^{-}$ions are very small and can compete with $\mathrm{O}_{2}^{-}$migration through the oxide layer. It has been noted that $\mathrm{F}^{-}$ions can migrate at a rate twice that of $\mathrm{O}_{2}{ }^{-}$ions through oxide layer, resulting in a fluoride layer formation at the metal-oxide interface [13]. When the anodizing is performed at an acidic $\mathrm{pH}$ value most of the $\mathrm{F}^{-}$ions are in the HF form. The diameter of the $\mathrm{TiO}_{2}$ nanotubes that grow in an HF electrolyte was reported to be between $15 \mathrm{~nm}$ and $140 \mathrm{~nm}$ [8].

The time of successful anodization increases with increasing the electrolyte $\mathrm{pH}$; in fact, formed nanotubes are longer when obtained in alkaline environment compared to nanotubes formed in electrolytes with a lower $\mathrm{pH}$ [14]. Also, it was shown that the slightly acidic $\mathrm{pH}$ value influences the formation of long and smooth tubes [15]. The titanium-based layers are more hydrophobic than other layers formed in a buffered electrolyte. The hydrophilic value at the interface between the implant material surface and the living tissue is a crucial factor in cell adhesion. An organic electrolyte has a small quantity of oxygen in comparison to an aqueous solution. Nanotubes with a diameter of 20-160 nm were obtained at an applied potential varied between 30 and 120 V using an organic electrolyte [16].

Potential difference and current density applied during the anodization process can vary within an extensive range of values [17]. The polarization potential varies between few volts and $250 \mathrm{~V}$ depending on the desired oxide characteristics. In fact, low potential $(1-130 \mathrm{~V})$ leads to the achievement of a smooth, amorphous and about 3$100 \mathrm{~nm}$ thick oxide film [17]. Contrary, the high potentials (100-250 V) combined with high current densities, lead to the formation of an oxide layer whose thickness vary between few tens to hundreds micrometers. The surface oxide film formation includes several steps [8]. Initially, the natural $\mathrm{TiO}_{2}$ particles are grown, joined together forming a smooth surface. After that, in some surface areas cracks are developed and surface layer becomes porous. With increasing voltage values, the film breaks down locally, and regions of original and modified film develop simultaneously, with the latter occupying more of the surface as the voltage rises. When the voltage is high, $\mathrm{TiO}_{2}$ film formation occurs because of the migration of $\mathrm{O}_{2}{ }^{-}$ions into the metal/film interface and migration of the $\mathrm{Ti}_{4}{ }^{+}$ions from metallic $\mathrm{Ti}$ to the film/ electrolyte interface [8].

The applied voltage and the anodizing time also affect the shape of the formed nanotubes $[18,19]$. For example, in a water-free electrolyte consisting of acetic acid and $\mathrm{NH}_{4} \mathrm{~F}$, under low potential conditions diameter of the formed nanotubes is about $20 \mathrm{~nm}$ while their maximum length is $100 \mathrm{~nm}$ [20]. At lower anodizing voltages, the thickness of the obtained oxide layer does not exceed $300 \mathrm{~nm}$ [21]. The mean increase of the oxide layer thickness on the Ti-13Nb-13Zr alloy surface is 3-4 $\mathrm{nmV}^{-1}$. The increase of the voltage to $140 \mathrm{~V}$ causes the increase of the oxide layer thickness to more than $1 \mu \mathrm{m}$ [21]. Some studies have shown that the increase of voltage from $10 \mathrm{~V}$ to $25 \mathrm{~V}$ can 
bring out the pore diameter from $30 \mathrm{~nm}$ to $150 \mathrm{~nm}$, but above $30 \mathrm{~V}$ the nanotubular structure is completely destroyed [22].

It was observed that the nanotube diameter increases with increasing voltage, but that is not affected by time [23]. The nanotube diameter can be increased linearly with the applied potential increase if the electrolyte $\mathrm{pH}$ value remains constant. The tube diameter is $\mathrm{pH}$ independent if the applied potential remains constant. Saji et al. [24] showed that the diameters of the tubes may vary in the range of 25-110 $\mathrm{nm}$. The average of the smallest and largest nanotubes diameter increases from $25 \mathrm{~nm}$ and $60 \mathrm{~nm}$ to 40 $\mathrm{nm}$ and $110 \mathrm{~nm}$, respectively, when the potential was increased from $10 \mathrm{~V}$ to $25 \mathrm{~V}$. In the above mentioned study, the average length of the nanotubes was $2 \mu \mathrm{m}$.

Minimal time necessary to create the nanotubular surface structure is between 30 $\min$ and $120 \mathrm{~min}$ [22]. However, the anodizing time also influences the thickness of the nanotubular layer. The anodizing time increase can increase the thickness of the formed nanotube oxide layer [8]. However, if anodizing is carried out for extended periods of time, nanotubular walls are thinned out [13]. Ossowska et al. [22] increased anodizing time from $0.5 \mathrm{~h}$ to $1 \mathrm{~h}$ and showed that the anodizing time had small effect on the nanotubes, mainly increasing their length. $\mathrm{A} \mathrm{TiO}_{2}$ nanotube layer, which has a maximum layer thickness of $1 \mu \mathrm{m}$ was formed in an acidic electrolyte consisting of fluoride salt at an applied potential of $20 \mathrm{~V}$ [25]. Beranek et al. [26] showed that with the optimal voltage of $20 \mathrm{~V}$ and the optimal anodizing time of $12 \mathrm{~h}$ in the $\mathrm{H}_{2} \mathrm{SO}_{4}$ and $\mathrm{H}_{3} \mathrm{PO}_{4}$ electrolyte the $\mathrm{TiO}_{2}$ nanotube maximum length of $500 \mathrm{~nm}$ can be achieved. On the other hand, $\mathrm{TiO}_{2}$ nanotubes with a diameter of $70-100 \mathrm{~nm}$ can be formed in less than $2 \mathrm{~h}$ when anodization occurs at an applied potential of $20 \mathrm{~V}$ in the electrolyte which consists of HF [27,28].

\section{Properties of nanotubes formed on Ti-based materials for biomedical applications}

Electrochemical anodization technique under optimized conditions is an efficient and economic approach for the production of self-ordered nanotubular structure on biomaterial surface $[29,30]$. $\mathrm{TiO}_{2}$ nanotubes with different diameters (from $15 \mathrm{~nm}$ up to $300 \mathrm{~nm}$ ) and different lengths can be grown by anodization of titanium or its alloys. $\mathrm{TiO}_{2}$ nanotubes can be obtained on all titanium alloys containing transition metals, such as Ti-6Al-7Nb, Ti-6Al-4V and Ti-Zr alloys with different $\mathrm{Zr}$ concentrations or on other alloys developed or tested for biomedical applications. During anodization $\mathrm{TiO}_{2}$ nanotubes that are open at the top and closed at the bottom, and are of different sizes, can be formed by changing the concentration and type of electrolyte and the anodizing time and voltage [8]. In addition, the size and shape of nanostructured materials can be tuned to the desire dimensions.

In general, after anodization the composition of the formed oxide layer is consistent with the alloy composition and alloying elements ratio [23,31]. For instance, the anodic oxide nanotubular layers on $\mathrm{Ti}-\mathrm{Al}$ alloys are composed of $\mathrm{TiO}_{2}$ and $\mathrm{Al}_{2} \mathrm{O}_{3}$ and in the case of $\mathrm{Ti}-6 \mathrm{Al}-7 \mathrm{Nb}$ alloy the surface layer is composed of $\mathrm{TiO}_{2}, \mathrm{Al}_{2} \mathrm{O}_{3}$, and $\mathrm{Nb}_{2} \mathrm{O}_{5}$ [21]. The fraction of these types of oxides is the respective fraction of $\mathrm{Ti}, \mathrm{Al}$ and $\mathrm{Nb}$ in the base alloys. Mosialek et al. [21] showed that the chemical composition of the electropolished Ti-13Nb-13Zr alloy surface $(\mathrm{Ti} / \mathrm{Zr} / \mathrm{Nb}=4.0: 0.55: 1)$ is similar to the composition of the alloy $(\mathrm{Ti} / \mathrm{Zr} / \mathrm{Nb}=5.6: 1: 1)$, but that the surface is depleted in titanium and zirconium. The chemical composition of the surface oxide layer formed at 
$100 \mathrm{~V}(\mathrm{Ti} / \mathrm{Zr} / \mathrm{Nb}=12.6: 1: 1)$ is similar to air-formed native oxide layer on that alloy $(\mathrm{Ti} / \mathrm{Zr} / \mathrm{Nb}=12.7: 1.2: 1)$, which is composed mainly of $\mathrm{TiO}_{2}, \mathrm{ZrO}_{2}$, and $\mathrm{Nb}_{2} \mathrm{O}_{5}$, with a small amount of $\mathrm{TiO}$ and $\mathrm{Ti}_{2} \mathrm{O}_{3}$ [24]. Anodization of the $\mathrm{Ti}-13 \mathrm{Nb}-13 \mathrm{Zr}$ alloy surface at lower potential $(10 \mathrm{~V})$ resulted in formation of the spongy-porous oxide layer with pore sizes in the range of $10-20 \mathrm{~nm}$. At higher potential (40V), compact porous oxide layer with pore size in the range of 50-100 $\mathrm{nm}$ was obtained. Chemical analysis of the formed nanotubes showed that nanotubes were composed of three constituent elements of the alloy and the presence of $\mathrm{Nb}$ and $\mathrm{Zr}$ oxides in the nanotubes was confirmed [32]. Thus it can be believed that the nanotubes formed on alloy may have enhanced mechanical properties and adhesion to the substrate.
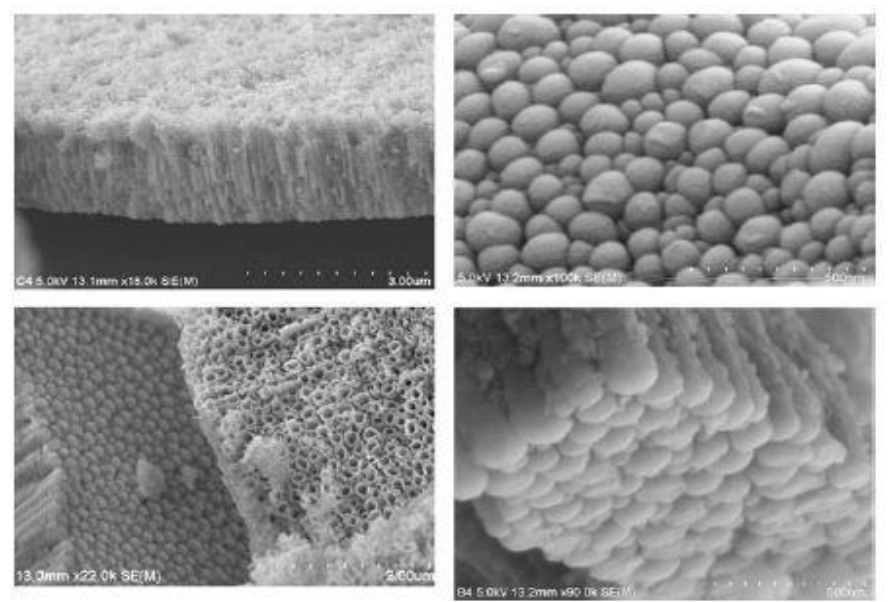

Fig. 2. SEM micrographs of nanotubular layer formed at $25 \mathrm{~V}$ during $180 \mathrm{~min}$ long anodization process [32].

Nanotubular oxide layer significantly increases the osteoblasts or bone cell adhesion to the titanium-based material surfaces compared to their non-anodized counter parts [7]. The nanotube layer plays a major role in improving the implant osseointegration through the adhesion improvement of hydroxyapatite (HAP) coating. Also, there are many studies dealing with the effect of the nanotube length and wall thickness on the surface roughness, corrosion resistance and biocompatibility of the metallic implant materials [33-37]. Detailed overview of already published research results regarding the effect of electrochemical anodization process on the Ti-based materials properties is given in Table 1. 
Table 1. The effects of electrochemical anodization process on the Ti-based materials properties [7,12,17,21,22,24,32,36-44].

\begin{tabular}{|c|c|c|c|c|}
\hline Reference & $\begin{array}{l}\text { Implant } \\
\text { material }\end{array}$ & $\begin{array}{l}\text { Anodization } \\
\text { conditions }\end{array}$ & $\begin{array}{l}\text { Examined } \\
\text { properties of } \\
\text { anodized } \\
\text { material }\end{array}$ & $\begin{array}{l}\text { Obtained research } \\
\text { results }\end{array}$ \\
\hline $\begin{array}{l}\text { N.A. Al-Mobarak } \\
\text { et al. [7] }\end{array}$ & cpTi & $\begin{array}{l}\text { Electrolyte: } \\
1 \mathrm{M} \mathrm{Na} \mathrm{SO}_{4}+ \\
0.5 \text { wt. } \% \mathrm{NaF}^{2} \\
1 \mathrm{M} \mathrm{H}_{3} \mathrm{PO}_{4}+ \\
0.8 \text { wt. } \% \mathrm{NaF} \\
0.5 \text { wt. } \% \mathrm{HF}\end{array}$ & \begin{tabular}{|l|} 
Corrosion \\
resistance \\
(electrochemical \\
measurements)
\end{tabular} & $\begin{array}{l}\text { The electrochemical } \\
\text { measurement results } \\
\text { indicate that the } \\
\text { electrochemical stability } \\
\text { of the nanotubular surface } \\
\text { depends on the formed } \\
\mathrm{TiO}_{2} \text { nanotubes diameter. } \\
\text { Larger nanotube diameter } \\
\text { decreases corrosion } \\
\text { resistance. }\end{array}$ \\
\hline $\begin{array}{l}\text { N.A. El-Wassefy } \\
\text { et al. [12] }\end{array}$ & $\begin{array}{l}\text { cpTi } \\
\text { (grade 2) }\end{array}$ & $\begin{array}{l}\text { Electrolyte: } \\
1 \mathrm{M} \mathrm{H}_{2} \mathrm{SO}_{4} \\
\text { Voltage: } \\
200 \mathrm{~V} \\
\text { Time: } \\
5 \mathrm{~min} \\
\end{array}$ & $\begin{array}{l}\text { Surface } \\
\text { characterization } \\
(\text { AFM, SEM) }\end{array}$ & $\begin{array}{l}\text { Anodization increased the } \\
\text { surface roughness. Also, } \\
\text { the surface area increased } \\
\text { linearly with increasing } \\
\text { the anodization time }\end{array}$ \\
\hline $\begin{array}{l}\text { M.V. Diamanti et } \\
\text { al. [17] }\end{array}$ & $\begin{array}{l}\text { cpTi } \\
\text { (grade 2) }\end{array}$ & $\begin{array}{l}\text { Electrolyte: } \\
0.25-2 \mathrm{M} \mathrm{H}_{2} \mathrm{SO}_{4} \\
\text { Current: } \\
\text { 100-1080 A/m }{ }^{2} \\
\text { Voltage: } \\
10-150 \mathrm{~V}\end{array}$ & $\begin{array}{l}\text { Surface } \\
\text { characterization } \\
(X R D)\end{array}$ & $\begin{array}{l}\text { Surface oxide conversion } \\
\text { to anatase is promoted } \\
\text { either by an increase in } \\
\text { current density or by a } \\
\text { decrease in sulphuric acid } \\
\text { concentration. }\end{array}$ \\
\hline $\begin{array}{l}\text { M. Mosialek et al. } \\
{[21]}\end{array}$ & Ti-13Nb-13Zr & $\begin{array}{l}\text { Electrolyte: } \\
\mathrm{H}_{3} \mathrm{PO}_{4}\end{array}$ & $\begin{array}{l}\text { Surface } \\
\text { characterization } \\
\text { (SEM, XPS) } \\
\text { Corrosion } \\
\text { resistance } \\
\text { (electrochemical } \\
\text { measurements) }\end{array}$ & $\begin{array}{l}\text { The alloy oxide layer } \\
\text { shows very high corrosion } \\
\text { resistance. }\end{array}$ \\
\hline
\end{tabular}




\begin{tabular}{|c|c|c|c|c|}
\hline Reference & $\begin{array}{l}\text { Implant } \\
\text { material }\end{array}$ & $\begin{array}{l}\text { Anodization } \\
\text { conditions }\end{array}$ & $\begin{array}{l}\text { Examined } \\
\text { properties of } \\
\text { anodized } \\
\text { material }\end{array}$ & $\begin{array}{c}\text { Obtained research } \\
\text { results }\end{array}$ \\
\hline $\begin{array}{l}\text { A. Ossowska et } \\
\text { al. [22] }\end{array}$ & Ti-13Nb-13Zr & $\begin{array}{l}\text { Electrolyte: } \\
1 \mathrm{M} \mathrm{H} \mathrm{PO}_{4}+ \\
0.3 \% \text { or } 0.5 \% \\
\mathrm{HF} \\
\text { Voltage: } \\
20 \mathrm{~V} \\
\text { Time: } \\
0.5 \text { or } 1 \mathrm{~h} \\
\text { Temperature: } \\
\text { room } \\
\text { temperature }\end{array}$ & $\begin{array}{l}\text { Surface } \\
\text { characterization } \\
\text { (SEM, EDS) } \\
\text { Corrosion } \\
\text { resistance } \\
\text { (electrochemical } \\
\text { measurements) } \\
\text { Nanohardness } \\
\text { and } \\
\text { microhardness } \\
\text { measurements } \\
\text { Young's } \\
\text { modulus } \\
\text { determination } \\
\text { Nanoscratch } \\
\text { tests }\end{array}$ & $\begin{array}{l}\text { The length of nanotubes } \\
\text { ranges between } 1 \mu \mathrm{m} \text { and } \\
2 \mu \mathrm{m} \text {, while their } \\
\text { diameter is in the range } \\
\text { between } 40 \mathrm{~nm} \text { and } 120 \\
\mathrm{~nm} \text {. } \\
\text { The nanotubular oxide } \\
\text { structure is observed to } \\
\text { increase the corrosion } \\
\text { resistance of the alloy. } \\
\text { Nanohardness, } \\
\text { microhardness and } \\
\text { Young's modulus values } \\
\text { are significantly lower. } \\
\text { The Young's modulus of } \\
\text { the nanotubular layer can } \\
\text { be } 36-43 \text { GPa. } \\
\text { The results of nanoscratch } \\
\text { tests show that the TiO } \\
\text { layer is removed from the } \\
\text { substrate earlier for non- } \\
\text { anodized sample. }\end{array}$ \\
\hline V. Saji at al. [24] & Ti-13Nb-13Zr & $\begin{array}{l}\text { Electrolyte: } \\
1 \mathrm{M} \mathrm{H}_{3} \mathrm{PO}_{4}+ \\
0.5 \mathrm{wt} . \% \mathrm{NaF} \\
\text { Voltage: } \\
\text { different } \\
\text { voltages } \\
\text { Time: } \\
\text { different } \\
\text { duration } \\
\text { Temperature: } \\
\text { room } \\
\text { temperature }\end{array}$ & $\begin{array}{l}\text { Surface } \\
\text { characterization } \\
\text { (SEM, XRD, } \\
\text { TEM) }\end{array}$ & $\begin{array}{l}\text { Nanotubes with diameter } \\
\text { in the range of } 25-110 \mathrm{~nm} \\
\text { can be formed on alloy } \\
\text { surface. }\end{array}$ \\
\hline
\end{tabular}




\begin{tabular}{|c|c|c|c|c|}
\hline Reference & $\begin{array}{l}\text { Implant } \\
\text { material }\end{array}$ & $\begin{array}{l}\text { Anodization } \\
\text { conditions }\end{array}$ & $\begin{array}{l}\text { Examined } \\
\text { properties of } \\
\text { anodized } \\
\text { material }\end{array}$ & $\begin{array}{c}\text { Obtained research } \\
\text { results }\end{array}$ \\
\hline V. Saji et al [32] & Ti-13Nb-13Zr & $\begin{array}{l}\text { Electrolyte: } \\
1 \mathrm{M} \mathrm{H}_{3} \mathrm{PO}_{4}+ \\
0.5 \mathrm{wt} . \% \mathrm{NaF} \\
\text { Temperature: } \\
\text { room } \\
\text { temperature }\end{array}$ & $\begin{array}{l}\text { Surface } \\
\text { characterization } \\
\text { (SEM, XRD, } \\
\text { TEM) } \\
\text { Corrosion } \\
\text { resistance } \\
\text { (electrochemical } \\
\text { measurements) }\end{array}$ & \begin{tabular}{|l} 
Anodization of the Ti- \\
$13 \mathrm{Nb}-13 \mathrm{Zr}$ alloy \\
decreases its corrosion \\
resistance. \\
The alloy after \\
nanotubular oxide layer \\
formation exhibited \\
significantly higher \\
corrosion current density \\
than the bare alloy. The \\
lower corrosion resistance \\
of the nanotubular alloy \\
was suggested to be \\
associated with the \\
distinctly separated \\
barrier oxide/concave \\
shaped tube bottom \\
interface.
\end{tabular} \\
\hline J. Park et al. [38] & $\begin{array}{l}\text { cpTi } \\
\text { (grade 3) }\end{array}$ & $\begin{array}{l}\text { Electrolyte: } \\
0.5 \% \mathrm{H}_{3} \mathrm{PO}_{4} \\
1 \% \mathrm{H}_{3} \mathrm{PO}_{4} \\
2 \% \mathrm{H}_{3} \mathrm{PO}_{4}\end{array}$ & $\begin{array}{l}\text { Surface } \\
\text { characterization } \\
\text { (SEM, XRD, } \\
\text { optical } \\
\text { profilometry, } \\
\text { contact angle, } \\
\text { surface energy) } \\
\text { ICP-MS } \\
\text { Biocompatibility }\end{array}$ & $\begin{array}{l}\text { Phosphoric acid as an } \\
\text { electrolyte increases the } \\
\text { biocompatibility of the } \\
\text { alloy by improving the } \\
\text { osteoblasts binding to the } \\
\text { medium surface. }\end{array}$ \\
\hline $\begin{array}{l}\text { A. Ossowska et } \\
\text { al. [39] }\end{array}$ & Ti-13Nb-13Zr & $\begin{array}{l}\text { Electrolyte: } \\
2 \mathrm{M} \mathrm{H} \mathrm{HOO}_{4}+ \\
0.3 \mathrm{wt} \% \% \mathrm{HF} \\
\text { Time: } \\
30 \mathrm{~min} \text { or } 1 \mathrm{~h}\end{array}$ & \begin{tabular}{|l|} 
Corrosion \\
resistance \\
(electrochemical \\
measurements)
\end{tabular} & $\begin{array}{l}\text { Anodization of the Ti- } \\
13 \mathrm{Nb}-13 \mathrm{Zr} \text { alloy } \\
\text { increases its corrosion } \\
\text { resistance. }\end{array}$ \\
\hline
\end{tabular}




\begin{tabular}{|c|c|c|c|c|}
\hline Reference & $\begin{array}{l}\text { Implant } \\
\text { material }\end{array}$ & $\begin{array}{l}\text { Anodization } \\
\text { conditions }\end{array}$ & $\begin{array}{c}\text { Examined } \\
\text { properties of } \\
\text { anodized } \\
\text { material }\end{array}$ & $\begin{array}{l}\text { Obtained research } \\
\text { results }\end{array}$ \\
\hline $\begin{array}{l}\text { A. Zielinski et al. } \\
{[40]}\end{array}$ & Ti-13Zr-13Nb & $\begin{array}{l}\text { Electrolyte: } \\
1 \mathrm{M} \mathrm{H}_{3} \mathrm{PO}_{4}+ \\
0.5 \% \mathrm{HF} \\
\text { Voltage: } \\
20 \mathrm{~V} \\
\text { Time: } \\
60 \text { min } \\
\text { Temperature: } \\
24^{\circ} \mathrm{C}\end{array}$ & $\begin{array}{l}\text { Surface } \\
\text { characterization } \\
\text { (AFM) } \\
\text { Nanoscratch } \\
\text { tests }\end{array}$ & $\begin{array}{l}\text { Nanotubes with diameter } \\
\text { in the range of } 80-120 \mathrm{~nm} \\
\text { and } 1 \mathrm{~mm} \text { in length can } \\
\text { be formed on the alloy } \\
\text { surface. } \\
\text { Hydroxyapatite coated } \\
\text { sample shows an initial } \\
\text { failure as the } \\
\text { hydroxyapatite coating is } \\
\text { likely delaminated from } \\
\text { the TiO layer. Later, the } \\
\mathrm{TiO}_{2} \text { layer became } \\
\text { penetrated in another } \\
\text { separate event. } \\
\text { The nanomeasurements } \\
\text { show that the nanotubular } \\
\text { oxide layers formed on } \\
\text { the Ti-13Zr-13Nb alloy } \\
\text { surface by anodization in } \\
\text { the presence of } \\
\text { hydrofluoric acid } \\
\text { demonstrate high } \\
\text { mechanical properties. }\end{array}$ \\
\hline X. Zhu et al. [36] & $\begin{array}{l}\mathrm{cpTi} \\
\text { (grade 2) }\end{array}$ & $\begin{array}{l}\text { Electrolyte: } \\
\mathrm{H}_{3} \mathrm{PO}_{4} \\
\text { calcium- } \\
\text { glycerophospha } \\
\text { te }(\mathrm{Ca}-\mathrm{GP})+ \\
\text { calcium acetate } \\
\text { (CA) }\end{array}$ & $\begin{array}{l}\text { Biocompatibility } \\
\text { (osteoblasts } \\
\text { response) }\end{array}$ & $\begin{array}{l}\text { Surface roughness } \\
\text { becomes lower in } 0.2 \mathrm{M} \\
\mathrm{H}_{3} \mathrm{PO}_{4} \text { but enhances in } \\
0.03 \mathrm{M} \text { Ca-GP and } 0.15 \mathrm{M} \\
\text { CA. Anodized surfaces } \\
\text { showed micro-pores with } \\
\text { diameters up to } 0.5 \mathrm{~mm} \text { in } \\
0.2 \mathrm{M} \mathrm{H}_{3} \mathrm{PO}_{4} \text { and up to } 2 \\
\mathrm{~mm} \text { in } 0.03 \mathrm{M} \text { Ca-GP and } \\
0.15 \mathrm{M} \text { CA. } \\
\text { Cell attachment increased } \\
\text { as anodizing voltage, } \\
\text { thickness of oxides, } \\
\text { number and size of micro- } \\
\text { pores, and roughness } \\
\text { increased. }\end{array}$ \\
\hline
\end{tabular}




\begin{tabular}{|c|c|c|c|c|}
\hline Reference & $\begin{array}{l}\text { Implant } \\
\text { material }\end{array}$ & $\begin{array}{l}\text { Anodization } \\
\text { conditions }\end{array}$ & $\begin{array}{l}\text { Examined } \\
\text { properties of } \\
\text { anodized } \\
\text { material }\end{array}$ & $\begin{array}{c}\text { Obtained research } \\
\text { results }\end{array}$ \\
\hline $\begin{array}{l}\text { S. Eraković et al. } \\
\text { [41] }\end{array}$ & cpTi & $\begin{array}{l}\text { Electrolyte: } \\
\text { Fluorid } \\
\text { electrolyte } \\
\text { (fluorid } \\
\text { concentration } \\
0.05-0.3 \\
\mathrm{~mol} / \mathrm{dm}^{3} \text { ) }\end{array}$ & $\begin{array}{l}\text { Possibility of } \\
\text { HAP application } \\
\text { on the surface of } \\
\text { titanium } \\
\text { nanotubular } \\
\text { layer }\end{array}$ & $\begin{array}{l}\text { The anodizing acidic } \\
\text { environment allows the } \\
\text { obtainment of shorter } \\
\text { nanotubes, which have } \\
\text { proved to be a better } \\
\text { substrate for the } \\
\text { application of HAP } \\
\text { coatings. } \\
\text { After the anodization, } \\
\text { plates of titanium were } \\
\text { heat-treated and a more } \\
\text { defined structure of } \\
\text { nanotubular } \mathrm{TiO}_{2} \text { layer } \\
\text { was obtained. }\end{array}$ \\
\hline $\begin{array}{l}\text { J.U. Kim et al. } \\
\text { [37] }\end{array}$ & Ti-29Nb-xZr & $\begin{array}{l}\text { Electrolyte: } \\
1 \mathrm{M} \mathrm{H} \mathrm{HO}_{4}+ \\
0.8 \mathrm{wt} \% \mathrm{NaF}\end{array}$ & $\begin{array}{l}\text { Corrosion } \\
\text { resistance } \\
\text { (electrochemical } \\
\text { measurements) }\end{array}$ & $\begin{array}{l}\text { Anodization increases } \\
\text { corrosion resistance of the } \\
\text { alloy. } \\
\text { The nanotube oxides } \\
\text { formed on the Ti- } 29 \mathrm{Nb}- \\
\text { XZr alloy surface show } \\
\text { lower corrosion current } \\
\text { density compared to non- } \\
\text { treated sample. }\end{array}$ \\
\hline $\begin{array}{l}\text { E.J. Kim et al. } \\
{[42]}\end{array}$ & Ti-35Ta-xZr & $\begin{array}{l}\text { Electrolyte: } \\
\mathrm{H}_{3} \mathrm{PO}_{4}+ \\
0.8 w t . \% \mathrm{NaF} \\
\text { Temperature: } \\
\text { room } \\
\text { temperature }\end{array}$ & $\begin{array}{l}\text { Nanotubular } \\
\text { layer } \\
\text { characterization } \\
\text { (FE-SEM, EDX, } \\
\text { XRD) }\end{array}$ & $\begin{array}{l}\text { Nanotubes with a wide } \\
\text { range of diameters } \\
\text { (approximately } 150-200 \\
\mathrm{~nm} \text { ) and lengths } \\
(\text { approximately } 4-10 \mu \mathrm{m} \text { ) } \\
\text { can be formed on alloy } \\
\text { surface. }\end{array}$ \\
\hline V. Saji et al. [43] & $\begin{array}{l}\text { Ti-35Nb-5Ta- } \\
7 \mathrm{Zr} \\
\text { Ti-13Nb-13Zr }\end{array}$ & $\begin{array}{l}\text { Electrolyte: } \\
1 \mathrm{M} \mathrm{H}_{3} \mathrm{PO}_{4}+ \\
0.5 \mathrm{wt} \% \% \mathrm{NaF}\end{array}$ & $\begin{array}{l}\text { Nanotubular } \\
\text { layer } \\
\text { characterization }\end{array}$ & $\begin{array}{l}\text { Heat treatment had } \\
\text { significant influence on } \\
\text { the nanotube oxide } \\
\text { interface. }\end{array}$ \\
\hline
\end{tabular}




\begin{tabular}{|c|c|c|c|c|}
\hline Reference & $\begin{array}{l}\text { Implant } \\
\text { material }\end{array}$ & $\begin{array}{l}\text { Anodization } \\
\text { conditions }\end{array}$ & $\begin{array}{c}\text { Examined } \\
\text { properties of } \\
\text { anodized } \\
\text { material }\end{array}$ & $\begin{array}{c}\text { Obtained research } \\
\text { results }\end{array}$ \\
\hline X. Cui et al. [44] & $\mathrm{Ti}$ & $\begin{array}{l}\text { Electrolyte: } \\
\text { sulfuric acid } \\
\text { acetic acid } \\
\text { phosphoric acid } \\
\text { sodium sulfate } \\
\text { solutions } \\
\text { Voltage: } \\
\text { different } \\
\text { voltages } \\
\text { Time: } \\
1 \text { min } \\
\text { Temperature: } \\
\text { room } \\
\text { temperature }\end{array}$ & $\begin{array}{l}\begin{array}{l}\text { Surface } \\
\text { characterization }\end{array} \\
\text { Possibility of } \\
\begin{array}{l}\text { apatite layer } \\
\text { inducement }\end{array}\end{array}$ & $\begin{array}{l}\text { Anodic films consisting } \\
\text { of rutile and/or anatase } \\
\text { phases with porous } \\
\text { structures are formed on } \\
\text { titanium after anodizing } \\
\text { in } \mathrm{H}_{2} \mathrm{SO}_{4} \text { and } \mathrm{Na}_{2} \mathrm{SO}_{4} \\
\text { electrolytes, while } \\
\text { amorphous titanium films } \\
\text { are produced after } \\
\text { anodizing in } \mathrm{CH}_{3} \mathrm{COOH} \\
\text { and } \mathrm{H}_{3} \mathrm{PO}_{4} \text { electrolytes. } \\
\text { Titanium with the anatase } \\
\text { and/or rutile crystal } \\
\text { structure films show } \\
\text { excellent apatite-forming } \\
\text { ability and produce a } \\
\text { compact apatite layer } \\
\text { covering the entire } \\
\text { titanium surface. } \\
\text { However, titanium metal } \\
\text { with amorphous titanium } \\
\text { layer is not able to induce } \\
\text { apatite formation. }\end{array}$ \\
\hline
\end{tabular}

Biocompatibility is one of the most important features of the implant materials. Investigations regarding the influence of titanium nanotubes characteristics on the cellular response to the implant surface showed significant effect of the nanotubes diameter. It was observed that titanium nanotubes with diameters of $15-20 \mathrm{~nm}$ are optimal for increased cell adhesion $[45,46]$. In addition, research results showed that nanotubes with a diameter of about $15 \mathrm{~nm}$ considerably increase the cellular adhesion, while higher nanotubes diameter of about $100 \mathrm{~nm}$ led to programmed cell death (apoptosis) [45,47]. This effect was confirmed for different substrate materials such as $\mathrm{TiO}_{2}$ and $\mathrm{ZrO}_{2}$ [47]. Park et al. [38] investigated biocompatibility of commercially pure titanium (cp Ti), after anodization in phosphoric acid. This study showed that the anodizing process increases implant material biocompatibility in a manner that improves the binding of the osteoblasts to the implant surface.

Nanotubes diameter also influences the corrosion properties of the implant materials. Electrochemical measurements, performed in different environments, revealed that the material after anodization shows better corrosion resistance compared to material which is not subjected to anodization [21,22,39,40]. Al-Mobarak et al. [7] showed that the electrochemical stability of the nanotubular surface depends on the $\mathrm{TiO}_{2}$ nanotube diameter and that larger diameter decreases corrosion resistance of the anodized implant material. For instance, Ossowska et al. [39] investigated electrochemical behavior of Ti-13Nb-13Zr alloy before and after anodization and found 
that the $j_{c o r r}$ value is lower for anodizated alloy and that anodization of the alloy increases its corrosion resistance. Contrary to this study, Saji et al. [32] indicated that anodization of the $\mathrm{Ti}-13 \mathrm{Nb}-13 \mathrm{Zr}$ alloy decreases its corrosion resistance since the empty spaces present between nanotubes may be considered as corrosion weak spots.

For the hard tissue implant, the low Young's modulus of titanium and its alloys is considered an important factor because it leads to less stress shielding compared with other materials, and in the same time induces faster and healthier bone regeneration. Zielinski et al. [40] investigated mechanical properties of the nanotubular oxide layers formed on the Ti-13Zr-13Nb alloy by anodization in the presence of hydrofluoric acid and demonstrated their high mechanical properties. Ossowska et al. [22] showed that the value of Young's modulus is significantly lower for Ti-13Zr-13Nb alloy after anodization. The Young's modulus of the nanotubular oxide layer can be approximately 36-43 GPa, which is very close to the Young's modulus of bone.

One of the latest trends in the production of nanotubes is to combine a variety of substances in order to improve their characteristics and make them easier to apply to the implant material surface [48]. Investigations of $\mathrm{TiO}_{2}$ nanotubes are mainly concentrated on the aspects related to their diameter and height. These types of nanotubes typically grow in mono-layers. The formation of multi-layer $\mathrm{TiO}_{2}$ nanotubes by electrochemical anodization is not often mentioned in the literature. Some studies have reported that multi-layered nanotubes can be formed using two different electrolytes or by adjusting the anodization voltage [49,50]. Case studies showed that a two-step anodization process by changing voltage from high to low can effectively grow high-aspect-ratio $\mathrm{TiO}_{2}$ nanotube arrays $[49,50]$. As a consequence of high voltage and low-voltage application, large diameter nanotubes are formed at the top, while small diameter nanotubes are formed below.

\section{Conclusion}

Anodization of titanium or its alloys results in formation of surface $\mathrm{TiO}_{2}$ nanotubes with different diameters (from $15 \mathrm{~nm}$ up to $300 \mathrm{~nm}$ ) and different lengths. The diameter and the length of $\mathrm{TiO}_{2}$ nanotubes depend on the conditions of electrochemical anodization, such as concentration and $\mathrm{pH}$ of the electrolyte, applied potential and anodization time. The time of successful anodizing process increases with increasing the $\mathrm{pH}$ of the electrolyte, while the alkaline environment presence results in the formation of nanotubes with a longer length. Applied current density and potential can vary within an extensive range of values. Low potential (1-130 V) application leads to the obtainment of a smooth, about 3-100 nm thick oxide layer. Contrary to that, the high potentials (100-250 V) combined with high current densities, lead to the formation of an oxide layer which thickness can vary between few tens to hundreds micrometers. The nanotube diameter increases with increasing anodization voltage, but is not affected by anodization time. The tube diameter can be increased by increasing the applied potential if the electrolyte $\mathrm{pH}$ value remains constant, while the tube diameter is $\mathrm{pH}$ independent if the applied potential remains constant. The tube length or the thickness of the formed nanotubular layer increases with the increase of anodization time, but there is always a point at which the thickness remains constant with any further increase. 
Nanotubes fabricated on the implant material surface, offer great potential in improving cell adhesion, as well as corrosion resistance, biocompatibility and mechanical properties of Ti-based materials developed for biomedical applications.

\section{Acknowledgement}

The authors acknowledge the support from the Ministry of Education, Science and Technological Development of the Republic of Serbia through the project ON 174004

\section{References}

[1] M.T. Mohammed, Z.A. Khan, A.N. Siddiquee, World Academy of Science, Engineering and Technology, International Journal of Chemical, Molecular, Nuclear, Materials and Metallurgical Engineering 8 (2014) 822-827.

[2] H.S. Kim, W.J. Kim, Corr. Sci. 89 (2014) 331-337.

[3] Y. Okazaki, S. Rao, Y. Ito, T. Tateishi, Biomaterials 13 (1998) 1197-1215.

[4] D.M. Brunette, P. Tengvall, M. Textor, P. Thomsen, Titanium in medicine: Material Science, Surface Science, Engineering, Biological Responses and Medical Applications, Springer-Verlag GmbH, Berlin, Germany, 2001.

[5] J. Lausmaa, J. Electron. Spectrosc. Relat. Phenom. 81 (1996) 343-361.

[6] S. Prasad, M. Ehrensberger, M.P. Gibson, H. Kim, E.A. Monaco Jr, J. of Oral Biosci. 57 (2015) 192-199.

[7] N.A. Al-Mobarak, A.A. Al-Swayih, Int. J. Electrochem. Sci. 9 (2014) 32-45.

[8] S. Minagar, C.C. Berndt, J. Wanga, E. Ivanova, C. Wena, Acta Biomaterialia 8 (2012) 2875-2888.

[9] H. Ishizawa, M. Fugino, M. Ogino, J. Biomed. Mater. Res. 29 (1995) 1459-1468.

[10] Y.T. Sul, Biomaterials 24 (2003) 3893-3907.

[11] D.V. Portan, G.C. Papanicolaou, G. Jiga, M. Caposi, J. Appl. Electrochem. 42 (2012) 1013-1024

[12] N.A. El-Wassefy, I.M. Hammouda, A.N.E.A. Habib, G.Y. El-Awady, H.A. Marzook, Clin. Oral Impl. Res. 25 (2014) e1-e9.

[13] L.N. Wang, M. Jin, Y. Zheng, Y. Guan, X. Lu, J.L. Luo, Int. J. Nanomed. 9 (2014) 4421-4435.

[14] Q. Cai, L. Yang, Y. Yu, Thin Solid Films 515 (2006) 1802-1806.

[15] Q. Cai, M. Paulose, O.K. Varghese, C.A. Grimes, J. Mater. Res. 20 (2005) 203236.

[16] J. Wan, X. Yan, J. Ding, M. Wang, K. Hu, Mater. Charact. 60 (2009) 1534-1540.

[17] M.V. Diamanti, M.P. Pedeferri, Corr. Sci. 49 (2007) 939-948.

[18] D. Gong, C.A. Grimes, O.K. Varghese, W. Hu, R.S. Singh, Z. Chen, E.C. Dickey, J. Mater. Res. 16 (2001) 3331-3334.

[19] G.K. Mor, O.K. Varghese, M. Paulose, N. Mukherjee, C.A. Grimes, J. Mater. Res. 18 (2003) 2588-2593.

[20] H. Tsuchiya, J.M. Macak, L. Taveira, E. Balaur, A. Ghicov, K. Sirotna, Electrochem. Commun. 7 (2005) 576-580.

[21] M. Mosiałek, G. Nawrat, L. Szyk-Warszyńska, J. Żak, A. Maciej, K. Radwański, A. Winiarski, J. Szade, P. Nowak, W. Simka, J. Solid State Electrochem. 18 (2014) 3073-3080.

[22] A. Ossowska, S. Sobieszczyk, M. Supernak, A. Zielinski, Surf. Coat. Tech. 258 (2014) 1239-1248. 
[23] H. Tsuchiya, J. Nakata, S. Fujimoto, S. Berger, P. Schmuki: In Proceedings Porous semiconductors: a symposium held in memory of Vitali Parkhutik and Volker Lehmann. Eds.: P. Schmuki, U. Goesele, D.J. Lockwood, H. Foell, J.J. Kelly, Y.H. Ogata, Pennington, The Electrochemical Society of USA, 2008, p. 359.

[24] V. Saji, H.C. Choe, W.A. Brantley, J. Mater. Sci. 44 (2009) 3975-3982.

[25] B. Feng, X. Chu, J. Chen, J. Wang, X. Lu, J. Weng, J. Porous Mater. 17 (2009) 453-458.

[26] R. Beranek, H. Hildebrand, P. Schmuki, Electrochem. Solid-State Lett. 6 (2003) B12-B14.

[27] I. Demetrescu, D. Ionita, C. Pirvu, D. Portan, Mol. Cryst. Liq. Cryst. 521 (2010) 195-203.

[28] J. Zhao, X. Wang, R. Chen, L. Li, Solid State Commun. 134 (2005) 705-710.

[29] M.Z. Hu, P. Lai, M.S. Bhuiyan, C. Tsouris, B. Gu, M.P. Paranthaman, J. Gabitto, L. Harrison, J. Mater. Sci. 44 (2009) 2820-2827.

[30] H. Park, H.G. Kim, J. Trans. Electr. Electron. Mater. 11 (2010) 112-115.

[31] H. Tsuchiya, T. Akaki, J. Nakata, D. Terada, N. Tsuji, Y. Koizumi, Y. Minamino, P. Schmuki, S. Fujimoto, Corros. Sci 51 (2009) 1528-1533.

[32] V. Saji, H.C. Choe, Corr. Sci. 51 (2009) 1658-1663.

[33] R. Chiesa, E. Sandrini, M. Santin, G. Rondelli, A. Cigada, J. Appl. Biomater. \& Biomech. 1 (2003) 91-107.

[34] R. Rodriguez, K. Kim, L.J. Ong, J. Biomed. Mater. Res. 65 (2003) 352-358.

[35] X. Zhu, J. Chen, L. Scheideler, T. Altebaeumer, J. Geis-Gerstorfer, D. Kern, Cells Tissues Organs 178 (2004) 13-22.

[36] X. Zhu, J. Chen, L. Scheideler, R. Reichl, J. Geis-Gerstorfer, Biomaterials 25 (2004) 4087-4103.

[37] J.U. Kim, B.H. Kim, K. Lee, H.C. Choe, Y.M. Ko, J. Nanosci. Nanotechnol. 4 (2011) 1636-1639.

[38] J. Park, Y.J. Kim, J.H. Jang, T.G. Kwon, Y.C. Bae, J.Y. Suh, Acta Biomaterialia 6 (2010) 1661-1670.

[39] A. Ossowska, A. Zieliński, M. Supernak, Solid State Phenom. 183 (2012) 137-142.

[40] A. Zielinski, P. Antoniuk, K. Krzysztofowicz, Surface Eng. 30 (2014) 643-649.

[41] S. Eraković, V. Panić, B. Jokić, S. Stevanović, V. Mišković, Zaštita materijala, 51 (2010) 24-29.

[42] E.J. Kim, W.G. Kim, Y.H. Jeong, H.C. Cho, J. Nanosci. Nanotechnol. 8 (2011) 7433-7437.

[43] V. Saji, H.C. Choe, Met. Mater. Int. 2 (2011) 275-278.

[44] X. Cui, H.M. Kimb, M. Kawashitac, L. Wanga, T. Xionga, T. Kokubod, T. Nakamurae, Dental Mater. 25 (2009) 80-86.

[45] S. Bauer, J. Park, K. von der Mark, P. Schmuki, Europ. Cells Mater. 20 (2010) 16.

[46] J. Park, S. Bauer, K. von der Mark, P. Schmuki, Nano Lett. 7 (2007) 1686-1691.

[47] S. Bauer, J. Park, J. Faltenbacher, S. Berger, K. von der Mark, P. Schmuki, Integr. Biol. 1 (2009) 525-532.

[48] M. Hosseini, M.M. Momeni, M. Faraji, J. Appl. Electrochem. 40 (2010) 1421 1427.

[49] X. Wang, S. Zhang, L. Sun, J. Thin. Solid Films 519 (2011) 4694-4698.

[50] J.M. Macak, S. Albu, D.H. Kim, I. Paramasivam, S. Aldabergerova, P. Schmuki, J. Electrochem. Solid-State Lett. 10 (2007) K28-K31. 